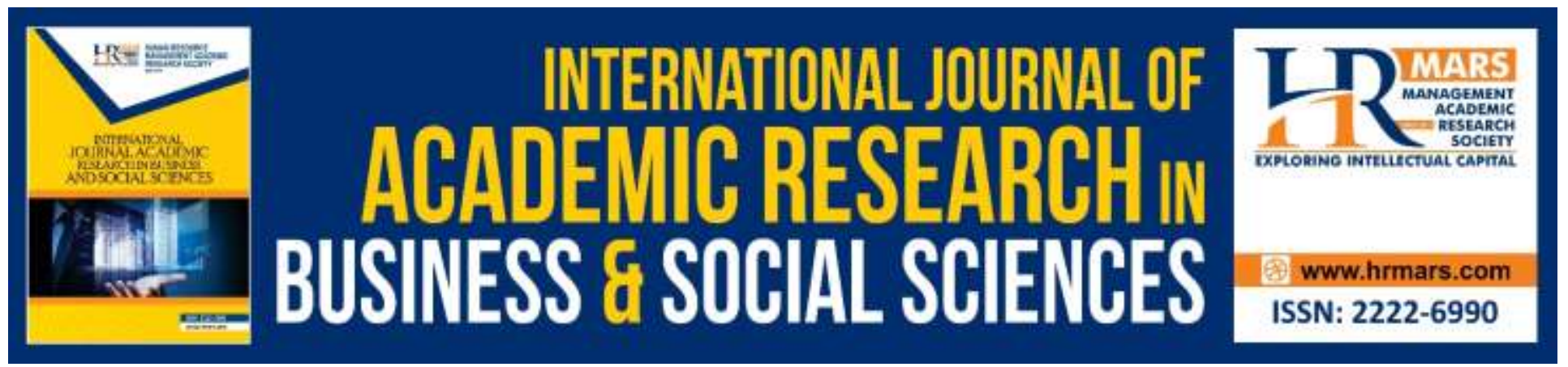

\title{
The Impact of Human Resource Management Practices on Perceived Business Performance: Evidence from Sri Lankan Manufacturing Firms
}

Lalith Nimal Senaweera, K A S Dhammika, N W K D K Dayarathna

To Link this Article: http://dx.doi.org/10.6007/IJARBSS/v10-i5/7233

DOI:10.6007/IJARBSS/v10-i5/7233

Received: 18 March 2020, Revised: 20 April 2020, Accepted: 29 April 2020

Published Online: 30 May 2020

In-Text Citation: (Senaweera et al., 2020)

To Cite this Article: Senaweera, L. N., Dhammika, K. A. S., \& Dayarathna, N. W. K. D. K. (2020). The Impact of Human Resource Management Practices on Perceived Business Performance: Evidence from Sri Lankan Manufacturing Firms. International Journal of Academic Research in Business and Social Sciences, 10(5), 591-608.

Copyright: (C) 2020 The Author(s)

Published by Human Resource Management Academic Research Society (www.hrmars.com)

This article is published under the Creative Commons Attribution (CC BY 4.0) license. Anyone may reproduce, distribute, translate and create derivative works of this article (for both commercial and non-commercial purposes), subject to full attribution to the original publication and authors. The full terms of this license may be seen at: $\underline{\text { http://creativecommons.org/licences/by/4.0/legalcode }}$

$$
\text { Vol. 10, No. 5, 2020, Pg. } 591-608
$$

Full Terms \& Conditions of access and use can be found at http://hrmars.com/index.php/pages/detail/publication-ethics 


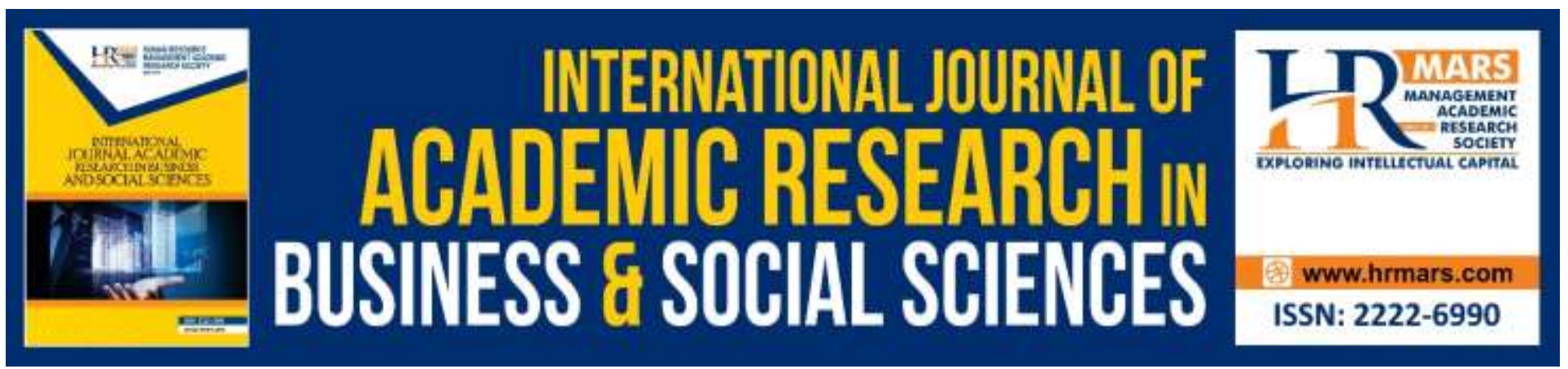

\title{
The Impact of Human Resource Management Practices on Perceived Business Performance: Evidence from Sri Lankan Manufacturing Firms
}

\section{Lalith Nimal Senaweera ${ }^{1}, \mathrm{~K}$ A S Dhammika ${ }^{2}$, N W K D K Dayarathna ${ }^{3}$}

\footnotetext{
${ }^{1}$ Former Chairman, Consumer Affairs Authority, No 31, Mallikarama Road, Ratmalana, Sri Lanka

${ }^{2}$ Department of Human Resource Management, University of Kelaniya, Sri Lanka, ${ }^{3}$ Department of Human Resource Management, University of Sri Jayawardenepura.
}

\begin{abstract}
The main objective of this paper is to investigate the impact of Human Resource Management Practices (HRMPs) on Perceived Business Performance (PBP) of ISO 9001 QMS certified manufacturing firms of Sri Lanka and also to examine the moderator effect of firm age on the relationship between HRMPs and PBP. The study was designed as a cross-sectional field survey and used a structured questionnaire technique to collect data from a sample selected using a simple random sampling technique from a known population and SPSS software is used for survey data analysis. The major finding indicates that overall HRMPs have no positive impact on PBP. However, training and development and recruitment and selection do have positive contributions to perceived business performance. Furthermore, the results indicate firm age has no moderating effect on the relationship between HRMPs and PBP. The findings of this paper are very much important for the Sri Lankan manufacturing industry and policymakers, as it provides clarity by identifying the important HRM practices, need to be focused when consider the enhancing of business performance(BP). Moreover, the results of the study are useful for manufacturing firms in Sri Lanka looking forward to installing ISO 9001 based quality management system within the firms as results provide human resource management practices areas need to be focused. This research is confined to ISO 9001QMS certified manufacturing firms of Sri Lanka and therefore the findings obtained may not be generalized to other countries.
\end{abstract}

Keywords: Human Resource Management Practices, Perceived Business Performance, Training and Development, Recruitment and Selection, Compensation and Rewards, ISO 9001 Quality Management System.

\section{Introduction}

In today's competitive world, manufacturing firms have to face many challenges to be competitive in the markets, and out of that one of the most important things is to have a unique competent set of 
employees within the firms and to that extent, Human Resource Management Practices play a vital role. Elarabi and Johari (2014) indicate that magnifying performance, acquiring and enhancing the expertise of employees, promoting working together among them to help organizational growth human resource management becomes a vital one. According to literature, certain studies show results that only a specific practice of Human Resource influences organizational performance (Shaw, Gupta \& Delery, 2005). Furthermore, research studies of scholars indicated that employees in an organization are a valuable factor to be competitive and therefore for organizational performance, HRM can play a vital role (Boselie \& Dietz, 2003).

In Sri Lanka, the manufacturing sector contributes heavily to the economy and these manufacturing firms have to manage a large number of employees and therefore most of these firms do have Human Resource departments or divisions. In other words, the human resource management function has a vital role to play in these firms to develop a set of competent and skilled staff to get the employees' contribution for the betterment of the organizations. Considering the stiff competition in the local and international markets the manufacturing firms have obtained ISO 9001 international certification. Hence, manufacturing firms in Sri Lanka have to comply with the best practices and that may help to streamline the HRM activities of these firms.

This study provides a significant contribution to the existing literature of Human Resource Management as in the Sri Lankan context very little studies were done to ascertain the impact of Human Resource Management Practices on perceived business performance in the context of ISO 9001 certified manufacturing firms. This study was conducted to address this gap in the literature and hence the findings of the study would help to obtain the effect of Human Resource Management Practices on Perceived Business Performance of the Sri Lankan ISO 9001 certified manufacturing firms. Moreover, the theoretical frame developed in this study using different sub-variables is a novel one and that would be an addition to the prevailing literature for further studies in the field of Human Resource Management practices and Business Performance. Furthermore, this study would also contribute significantly to potential manufacturing firms who are very much interested in obtaining ISO 9001 certification as it spotlights the variables of Human Resource Management Practices that need to give attention in enhancing business performance. The study support (a) to examine the impact of human resource management practices on perceived business performance (b) to investigate the impact of training and development on perceived business performance (c) to examine the impact of compensation and rewards on perceived business performance (d) to investigate the impact of recruitment and selection on perceived business performance and (e) to examine the moderator effect of firm age between human resource management practices and perceived business performance.

\section{Literature Review}

Hassan et al. (2006) mentioned that employees are human beings and value to the organization and therefore should be treated as humans by providing the necessary amenities which is a basic principle of Human Resource Management (HRM) and therefore, HRM covers areas like employee development so that their contribution can be obtained to support the organization improvement. As per the literature, a quite number of studies done in the area of Human Resource Management and Business Performance but the findings are not very specific. One of the vital issues in the theory is the debate of the exact mediating connection between HRM and the performance outcome. This is identified as the "black box" in the theory. Boxall et al. (2011) indicated that as per the extant 
INTERNATIONAL JOURNAL OF ACADEMIC RESEARCH IN BUSINESS AND SOCIAL SCIENCES Vol. 10, No. 5, May, 2020, E-ISSN: 2222-6990 @ 2020 HRMARS

literature the connection between HRM practices and performance was not specific and hence it is referred to as "black box" in the theory. Moreover, HRM practices may provide various results when used in a different context and hence the context plays an important role (Dieleman et al., 2009). Armstrong (2006) indicates that the basis of the human capital theory is that when people use the skills, abilities, and experience collectively for the betterment of the organization that is a significant contribution to the success of the organization and to gain competitive advantage. Furthermore, Barney (1991) indicated that resources are unique to the firm and not possible to replicate by the competitors. Lepak et al. (2006) indicated that in the argument of competitiveness of business human resource management has a major role in the formation and enhancement of motivated staff. Barney and Wright (1998) indicated that one of the unique, valuable, and important resource is human resource and it is vital for excellent performance leading to viable competitive advantage. According to Jiang et al. (2012), practices used for the development of employee competence and enhancement of motivation helps to obtain employee contribution. Shaw, Park, and Kim (2013) indicated that several previous studies considered to see the connection with the HRM practices and organizational performance variables.

\section{Human Resource Management Practices and Perceived Business Performance}

The management of workforce and enhancement of capabilities and skills to be unique to the organization to meet the challenges of more complicated societal needs whilst creating new organization-specific understanding to be competitive is considered as HRM practices (Brewster, Suutari, \& Minbaeva, 2005). Noe et al. (2011) argued that human resource needs to be managed effectively as that would help to model the varying qualities of the employees to the positive direction and therefore it is very important. Hutchison et al (2002) indicated the necessity of better understanding the processes of which HR practices would have an impact on performance. Empirical studies proved that the firms developed a mechanism to align HRM practices with business strategy showed excellent results (Becker \& Gerhart, 1996; Dyer \& Reeves, 1995). Huselid (1995) and Macduffie (1995) indicated that as per the previous studies HRM practices and systems support for the development and maintenance of competitive advantage for the firm. Moreover, Crook et al. (2011) mentioned that certain empirical studies show HRM and organizational performance are positively related. HRM Practices influenced on turnover (Guthrie, 2001). Mansour (2010) proved that HR practices (recruitment, training, participation, performance appraisal, and compensation) and firm performance positively connected. Some combination of HRM practices and operational performance are linked within manufacturing firms (Youndt et al., 1996). Given the above, the following hypothesis is proposed;

$\mathrm{H}_{1}$ Human Resource Management Practices have an impact on Perceived Business (Performance.

\section{Training and Development and Perceived Business Performance}

Lee and Lee (2007) proved that training and development contribute to the enhancement of firm performance covering employee's productivity, product quality, and firm's flexibility. Training and development influence employee productivity significantly (Chang \& Chen, 2002). According to Cook and Hunsaker (2001), for the enhancement of organizational performance and employee efficiency and effectiveness training is possible to use as a technique. Likewise, Holzer et al. (1993) through the study of manufacturing firms proved that workplace training has reduced the scrap rate of the firms leading to improved performance of the firms. According to Swanson (1995) development of human 
INTERNATIONAL JOURNAL OF ACADEMIC RESEARCH IN BUSINESS AND SOCIAL SCIENCES

Vol. 10, No. 5, May, 2020, E-ISSN: 2222-6990 @ 2020 HRMARS

expertise and enhancement of performance can be achieved with the support of personnel training and development and organizational development. Lee and Bruvold (2003) proved that complete training leads to having a positive connection between organizational performance and productivity. Hence the following hypothesis is proposed

$\mathrm{H}_{1 \mathrm{a}}$ Training and Development has an impact on Perceived Business Performance.

\section{Compensation and Rewards and Perceived Business Performance}

Compensation and rewards are used by organizations in a different form for employees to recognize their job wok which in turn helps to obtain employee commitment for the betterment of the organization. Normally a reward management system covers monetary and non-monetary rewards. Compensation is positively related to organizational performance (Frye, 2004). Compensation Strategy contributes significantly to the improvement of organization productivity (Obasan, 2012). According to Ajila and Abiloa (2004), rewarding employees using recognition and appreciation is a vital factor leading to organizational performance. Normally a reward system covers interconnected processes and functions which are together to help to execute an effective reward system for the betterment of the employees and the organization (Armstrong, 2009). A sound rewards system plays a major role in making an organization's capability to attract and retain competent and high performing employees leading to attaining improved levels of quality and performance (Fay \& Thompson, 2001). Vance (2012) indicated that an increasing need is there for an appropriate rewarding system to motivate employees to attain increased organizational performance. Given the above, the following hypothesis is proposed

$\mathrm{H}_{1 \mathrm{~b}}$ Compensation and Rewards have an impact on Perceived Business Performance.

\section{Recruitment and Selection and Perceived Business Performance}

Recruitment and selection play a vital role in any organization as that helps to get competent, talented, and committed employees to any organization. According to Soliman and Spooner (2000), organizations face issues in the relation of having an appropriate human resource pool and achieving expected profitability if the recruitment is not taken place properly and therefore recruitment is in the center of the management process. Recruitment and Selection are considered as one of the most important processes of an organization as organizations are considered that human capital is the unique factor to be competitive (Ntiamoah et al., 2014). Performance in organizations is positively related to the sophisticated recruitment and selection system (Rauf, 2007). In using a proper recruitment and selection system organizations were able to get the correct people to fill the unoccupied positions enabling organizations to achieve growth. The process uses for recruitment and selection of employees in an organization is connected with the organizational performance (Sarkar \& Kumar, 2007). Djabatey (2012) indicated the necessity of having the right staff is a key factor for an organization to build and sustain the competitive advantage. Given the above, the following hypothesis is proposed;

$\mathrm{H}_{1 \mathrm{c}}$ Recruitment and Selection have an impact on Perceived Business performance.

\section{Firm Age (number of Years that QMS implemented)}

Moreover, firm age indicates the number of years the ISO 9001 quality management system is implemented within a firm. In other words, this indicates that depending on the number of years the quality system implementation whether any influence is there from this variable to the relation 
between Human Resource Management Practices and Perceived Business Performance. Lai (2013) indicated that a moderator variable is one that influences the connection and or direction between the independent and dependent variables. According to the extant literature, Firm age has been used as a moderator variable in a different context (Bedi and Vij, 2015; Rafiq et al., 2016). Given the above, the following hypothesis is proposed;

H2: Firm Age moderates the relationship between Human Resource Management Practices and Perceived Business Performance

Considering the above information, the following hypothesized model is proposed to evaluate the Human Resource Management Practices of ISO 9001 QMS certified Sri Lankan manufacturing firms in Sri Lanka. The ISO 9001 QMS certified manufacturing firms are considered for the study and used three dimensions in assessing the hypothesized model used for this study

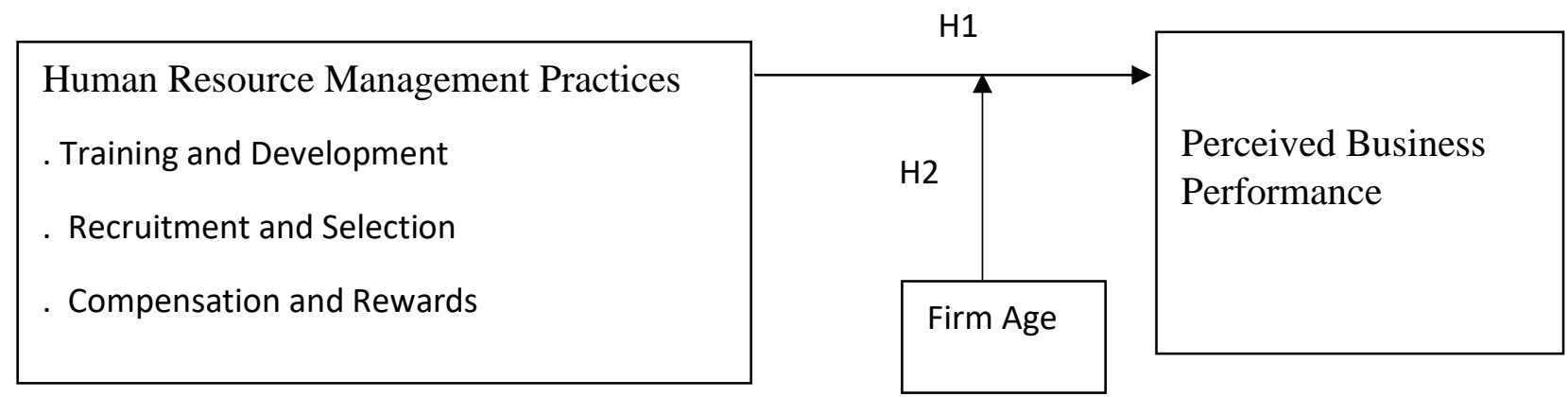

Figure 1- Hypothesized Model

\section{Methodology}

\section{Pilot Study}

A well-defined structured questionnaire was developed based on the understanding of the literature review and using previously validated items by different scholars. Under each main sub- variable questions are identified ensuring the categorization of questions and the questionnaire was further reviewed and refined with the support of the academic and industry experts and aligned to suit to Sri Lankan context. All questions in the questionnaire were developed using a 5 point Likert scale. The pilot study was done by sending 35 questionnaires to ISO 9001 certified organizations and the researcher received completed questionnaires. Those were reviewed and found that all questionnaires were properly completed and can be used for analysis. The researcher conducted the Exploratory Factor Analysis with Varimax rotation to determine the construct validity of the items used in the questionnaire and to ensure the reliability of data by conducting Cronbach's Alfa value test. Both tests satisfied all the requirements, for instance, Cronbach's Alfa values for all variables were greater than 0.7 and therefore the questionnaire was used without any modifications for the field survey to collect data for the main research.

\section{Population and Sampling}

Two hundred sixty-nine (269) ISO 9001 manufacturing firms were selected using a simple random sampling technique from a population of ISO 9001 Quality Management Systems certified manufacturing firms of Sri Lanka. To select the said sample size Sekaran and Bougie (2010) sampling tables and the nonresponse rate for the pilot sample were taken into consideration. The respondents for the study were senior managers, middle managers, and executives who are knowledgeable in the 
INTERNATIONAL JOURNAL OF ACADEMIC RESEARCH IN BUSINESS AND SOCIAL SCIENCES

Vol. 10, No. 5, May, 2020, E-ISSN: 2222-6990 ㄷ 2020 HRMARS

application of ISO 9001 quality management system practices within the manufacturing firms. Only 210 questionnaires were able to use as some questionnaires were incomplete.

\section{Data Analysis Techniques}

The data were analyzed using SPSS software 21 version and the tests like such as screening for missing data, normality tests, validity \& reliability test, descriptive statistics analysis, inferential statistics were used. The researcher conducted diagnostic tests such as linearity tests, homogeneity tests, and multicollinearity tests to determine the suitability of data for further analysis. Furthermore, multiple regression analysis and hierarchical regression techniques were used to test the hypotheses.

\section{Results and Discussion}

Demographic Characteristics of Respondents

Table 1- Age Categorization of Respondents

\begin{tabular}{|ll|l|l|l|l|}
\hline & & & & & Cumulative \\
\hline Valid & $25-30$ & 8 & 3.8 & 3.8 & 3.8 \\
& $31-35$ & 51 & 24.3 & 24.3 & 28.1 \\
& $36-40$ & 94 & 44.8 & 44.8 & 72.9 \\
& $41-45$ & 48 & 22.9 & 22.9 & 95.7 \\
& $46-50$ & 9 & 4.3 & 4.3 & 100.0 \\
\hline & Total & 210 & 100.0 & 100.0 & \\
\hline
\end{tabular}

Note. Survey Data

The above table indicates that most of the respondents are in the age group of 36-40 and therefore these respondents have matured employees and are around $44.8 \%$ and it may be possible to indicate that these officers do have requisite experience on ISO 9001 Quality Management System.

Table 2- Working Experience

\begin{tabular}{|ll|l|l|l|l|}
\hline & & & & & Cumulative \\
& & Frequency & Percent & Valid Percent & Percent \\
\hline Valid & $3-5$ & 13 & 6.2 & 6.2 & 6.2 \\
& $6-8$ & 74 & 35.2 & 35.2 & 41.4 \\
& $9-10$ & 75 & 35.7 & 35.7 & 77.1 \\
10 above & 48 & 22.9 & 22.9 & 100.0 \\
& Total & 210 & 100.0 & 100.0 & \\
\hline
\end{tabular}

Note. Survey Data

Above table 2 indicates that more than 93.8\% of employees do have more than six years' experience and that indicates the respondents have an adequate understanding of the HRM practices within their organizations and hence it can be considered the respondents' answers are more appropriate. The researcher calculated a criterion to discuss the descriptive statistics analysis of mean, standard deviation (SD) of the items in the questionnaire. The following three levels were identified as "High", "Moderate" and "Low" for interpretation of results. Since the items used for the questionnaire were based on the Likert scale, the level of each item based on its mean is calculated using (highest point 
INTERNATIONAL JOURNAL OF ACADEMIC RESEARCH IN BUSINESS AND SOCIAL SCIENCES

Vol. 10, No. 5, May, 2020, E-ISSN: 2222-6990 ㄷ 2020 HRMARS

in Likert scale - the lowest point in the Likert scale) / number of the levels used. Therefore, the interval between each level and the other $=1.33(5-1 / 3)$ and the following criterion is obtained:

"Low"- 1- 2.33, "Moderate" -2.34- 3.67 and "High"- 3.68- 5. The study results are as follows:

\section{Human Resource Management Practices}

The mean and Standard deviation were used to analyze Human Resource Management System Practices and details are presented below:

Training and Development

Table 3- Level of Consideration Given for Training and Development

\begin{tabular}{|c|c|c|c|c|c|}
\hline Rank & item & Descriptions & Mean & $\begin{array}{l}\text { Standard } \\
\text { Deviation }\end{array}$ & Mean Level \\
\hline 1. 1 & 1 & $\begin{array}{l}\text { The firm has a criterion to identify the } \\
\text { training needs of employees. }\end{array}$ & 3.96 & 0.724 & High \\
\hline 2. & 2 & $\begin{array}{l}\text { The firm prepares an overall training } \\
\text { schedule based on the identified training } \\
\text { needs of employees. }\end{array}$ & 3.89 & 0.768 & High \\
\hline 3 & 3 & $\begin{array}{l}\text { Training is given to employees based on } \\
\text { the identified training needs. }\end{array}$ & 3.88 & 0.819 & High \\
\hline 4. & 5 & $\begin{array}{l}\text { The firm encourages employees to } \\
\text { participate in relevant training \& } \\
\text { development Programs. }\end{array}$ & 3.86 & 0.788 & High \\
\hline 5 & 4 & $\begin{array}{l}\text { The frequency of the training programs } \\
\text { conducted by the firm is satisfactory. }\end{array}$ & 3.81 & 0.800 & High \\
\hline 6. & 6 & $\begin{array}{l}\text { There is a criterion within the firm to } \\
\text { measure the effectiveness of training. }\end{array}$ & 3.79 & 0.811 & High \\
\hline 7. & 7 & $\begin{array}{l}\text { Training \& development has resulted in } \\
\text { higher performance of employees in the } \\
\text { firm. }\end{array}$ & 3.77 & 0.805 & High \\
\hline 8. & 8 & $\begin{array}{l}\text { There is a formal induction, orientation, } \\
\text { and familiarization process designed to } \\
\text { help recruits to understand the firm. }\end{array}$ & 3.74 & 0.813 & High \\
\hline 9. & 8 & $\begin{array}{l}\text { There is a system to follow up training and } \\
\text { development programs within the firm. }\end{array}$ & 3.74 & 0.790 & High \\
\hline 10. & 9 & $\begin{array}{l}\text { The firm has a separate budget for training } \\
\text { and development work. }\end{array}$ & 3.73 & 0.792 & High \\
\hline & & Total Score (Overall) & 3.81 & 0.791 & High \\
\hline
\end{tabular}

The overall mean score of 3.81 indicates that the respondents have considered the importance of training and development activities of the ISO 9001 certified manufacturing firms and that activity is satisfactorily taking place according to the results. This is a very important finding as in general it appears that the Importance level of training and development was high in ISO 9001 QMS certified 
INTERNATIONAL JOURNAL OF ACADEMIC RESEARCH IN BUSINESS AND SOCIAL SCIENCES

Vol. 10, No. 5, May, 2020, E-ISSN: 2222-6990 @ 2020 HRMARS

manufacturing firms of Sri Lanka. In other words, one of the HRM practices of Training and Development is considered as very much required by these firms. The mean value of training and development items varied within (3.73 -3.96) when compared with the overall mean value of 3.81. As per the analysis the highest mean value was 3.9 for the statement "The firm has a criterion to identify the training needs of employees" with a standard deviation of 0.724 and indicates that these manufacturing firms agreed that the firms do have a proper criterion to identify the training needs of employees of these firms.

\section{Recruitment and Selection}

Table 4- Level of Consideration Given for Recruitment and Selection

\begin{tabular}{|c|c|c|c|c|c|}
\hline Rank & $\begin{array}{l}\text { Ite } \\
\text { m }\end{array}$ & Descriptions & Mean & $\begin{array}{l}\text { Standard } \\
\text { Deviation }\end{array}$ & Mean Level \\
\hline 1. & 3 & $\begin{array}{l}\text { Applicants are fully informed } \\
\text { about the job requirements need } \\
\text { to perform the job before being } \\
\text { hired. }\end{array}$ & 3.81 & 0.753 & High \\
\hline 2. & 7 & $\begin{array}{l}\text { The recruitment and selection } \\
\text { process in the firm is fair and } \\
\text { transparent. }\end{array}$ & 3.78 & 0.747 & High \\
\hline 3. & 1 & $\begin{array}{l}\text { The firm has a Scheme of } \\
\text { Recruitment (SOR) covering job } \\
\text { requirements for each } \\
\text { designation. }\end{array}$ & 3.76 & 0.801 & High \\
\hline 4. & 2 & $\begin{array}{l}\text { Job Advertisements are used by } \\
\text { the Firm in newspapers for the } \\
\text { recruitment of employees based } \\
\text { on SOR. }\end{array}$ & 3.74 & 0.739 & High \\
\hline 5. & 4 & $\begin{array}{l}\text { An interview panel comprising of } \\
\text { line managers and HR manager } \\
\text { participate in the interview panel } \\
\text { to select the suitable employee }\end{array}$ & 3.69 & 0.844 & High \\
\hline 6. & 6 & $\begin{array}{l}\text { Vacancies are also filled internally } \\
\text { from the qualified employees }\end{array}$ & 3.67 & 0.791 & moderate \\
\hline 7. & 5 & $\begin{array}{l}\text { Appointments are given purely } \\
\text { based on merit. }\end{array}$ & 3.62 & 0.774 & moderate \\
\hline & & Total Score (Overall) & 3.72 & 0.891 & High \\
\hline
\end{tabular}

Note. Survey Data,

The overall mean score of 3.72 indicates that the recruitment and selection activities of the ISO 9001 QMS certified manufacturing firms are given higher consideration to ensure that the right personnel is selected for the relevant job. The mean value of recruitment and selection items varied within (3.81 -3.62) when compared with the overall mean value of 3.72. As per the analysis the highest mean value was 3.81 for the statement "Applicants are fully informed about the job requirements need to perform the job before being hired" with a standard deviation of 0.753 indicates that these 
INTERNATIONAL JOURNAL OF ACADEMIC RESEARCH IN BUSINESS AND SOCIAL SCIENCES

Vol. 10, No. 5, May, 2020, E-ISSN: 2222-6990 @ 2020 HRMARS

manufacturing firms communicate the required information of the job tasks required to be performed so that employee is well aware what exactly to be performed before joining the firm. This is a very important finding as to the communication of job requirements to the potential applicants before hiring is very much important as then the applicant can consider whether he can do that job or not and make a correct decision so that both parties the candidate and the firm be benefited.

\section{Compensation and Rewards}

Table 5- Level of Consideration Given for Compensation and Rewards

\begin{tabular}{|c|c|c|c|c|c|}
\hline Rank & Item & Descriptions & Mean & $\begin{array}{l}\text { Standard } \\
\text { Deviation }\end{array}$ & Mean Leve \\
\hline 1. & 13 & $\begin{array}{l}\text { The current compensation and } \\
\text { reward system of the firm is } \\
\text { satisfactory }\end{array}$ & 3.83 & 0.703 & High \\
\hline 2. & 12 & $\begin{array}{l}\text { To encourage participation in } \\
\text { practice development, the firm } \\
\text { should acknowledge and } \\
\text { reward efforts as well as } \\
\text { results. }\end{array}$ & 3.74 & 0.762 & High \\
\hline 3. & 11 & $\begin{array}{l}\text { The firm has a system to } \\
\text { reward collaboration more } \\
\text { between practice groups. }\end{array}$ & 3.73 & 0.711 & High \\
\hline 4 & 9 & $\begin{array}{l}\text { The firm needs to pay more } \\
\text { attention to the profitability of } \\
\text { work performed in making } \\
\text { compensation to employees. }\end{array}$ & 3.72 & 0.743 & High \\
\hline 5. & 6 & $\begin{array}{l}\text { Job performance is an } \\
\text { important factor in determining } \\
\text { the incentives for } \\
\text { employees }\end{array}$ & 3.71 & 0.762 & High \\
\hline 6. & 8 & $\begin{array}{l}\text { Employees in the firm aware of } \\
\text { what need do to earn higher } \\
\text { compensation }\end{array}$ & 3.69 & 0.821 & High \\
\hline 7. & 5 & $\begin{array}{l}\text { Compensation packages } \\
\text { encourage employees to } \\
\text { achieve the firm's objectives }\end{array}$ & 3.68 & 0.715 & High \\
\hline 8 & 10 & $\begin{array}{l}\text { Building skills in others should } \\
\text { be explicitly rewarded }\end{array}$ & 3.67 & 0.757 & moderate \\
\hline 9 & 3 & $\begin{array}{l}\text { The current compensation \& } \\
\text { rewards system has clear } \\
\text { weights given to measurable } \\
\text { factors, rather than a judicial } \\
\text { system. }\end{array}$ & 3.66 & 0.714 & moderate \\
\hline
\end{tabular}


INTERNATIONAL JOURNAL OF ACADEMIC RESEARCH IN BUSINESS AND SOCIAL SCIENCES Vol. 10, No. 5, May, 2020, E-ISSN: 2222-6990 @ 2020 HRMARS

\begin{tabular}{|l|l|l|l|l|l|}
\hline 10 & 7 & $\begin{array}{l}\text { The firm constantly reviews and } \\
\text { updates the range of benefits } \\
\text { such as health, accident, } \\
\text { liability protection, \& house } \\
\text { rent, etc. to meet the needs of } \\
\text { the employees. }\end{array}$ & 0.805 & moderate \\
\hline 11 & 4 & $\begin{array}{l}\text { Employees have received } \\
\text { recognition/rewards for doing } \\
\text { good work. }\end{array}$ & 3.64 & 0.768 & moderate \\
\hline 12 & 1 & $\begin{array}{l}\text { Employees are satisfied with } \\
\text { the salary given by the firm. }\end{array}$ & 3.63 & 0.773 & moderate \\
\hline & $\begin{array}{l}\text { Salary increments, bonuses, } \\
\text { and other allowances } \\
\text { (incentives) are reviewed fairly } \\
\text { and justifiably. }\end{array}$ & 3.62 & 0.718 & moderate \\
\hline
\end{tabular}

The overall mean score of 3.67 indicates that compensation and rewards activities of the ISO 9001 QMS certified manufacturing firms are given a moderate level of consideration to motivate and retain the staff as that ensures the smooth operation of the functions of these firms. The mean value of compensation and rewards items varied within (3.83 -3.62) when compared with the overall mean value of 3.67. As per the analysis the highest mean value was 3.83 for the statement "The current compensation and reward system of the firm is satisfactory" with a standard deviation of 0.703 indicates that these manufacturing firms provide adequate compensation and rewards to the employees so that the employees motivate to carry out job tasks efficiently and it also helps to retain talented employees within the firm.

\section{Summary of Descriptive Statistics}

Table 6- Overall Mean and Standard Deviation values

\begin{tabular}{|l|l|l|}
\hline Variable & Overall Mean & $\begin{array}{l}\text { Overall Standard } \\
\text { Deviation }\end{array}$ \\
\hline $\begin{array}{l}\text { Training and } \\
\text { Development }\end{array}$ & 3.81 & 0.791 \\
\hline $\begin{array}{l}\text { Recruitment and } \\
\text { Selection }\end{array}$ & 3.72 & 0.891 \\
\hline $\begin{array}{l}\text { Compensation and } \\
\text { Rewards }\end{array}$ & 3.67 & 0.750 \\
\hline
\end{tabular}

\section{Survey Data}

Table 6 indicates the overall mean and standard deviation values of the sub variables and the main variable. The summary of results indicates that overall mean values were over the 2.5 midpoints and the standard deviation varied in the range of 0.750 to 0.891 leading a narrow spread of data within the mean. 
INTERNATIONAL JOURNAL OF ACADEMIC RESEARCH IN BUSINESS AND SOCIAL SCIENCES Vol. 10, No. 5, May, 2020, E-ISSN: 2222-6990 @ 2020 HRMARS

Table 7- Cronbach's Alfa

\begin{tabular}{|l|l|l|}
\hline Variable & Cronbach's Alfa & Interpretation \\
\hline $\begin{array}{l}\text { Training and } \\
\text { Development }\end{array}$ & 0.736 & reliable \\
\hline $\begin{array}{l}\text { Recruitment and } \\
\text { Selection }\end{array}$ & 0.753 & reliable \\
\hline $\begin{array}{l}\text { Compensation and } \\
\text { Rewards }\end{array}$ & 0.862 & reliable \\
\hline $\begin{array}{l}\text { Human Resource } \\
\text { Management Practices }\end{array}$ & 0.806 & reliable \\
\hline
\end{tabular}

Survey Data

The researcher performed Cronbach's Alfa value test to determine the reliability of the data. Cronbach's Alpha is equal to or higher than 0.7 indicates a good value (Hair et al., 1998). More than or equal 0.7 value for alpha is more acceptable. Table 7 given below shows the reliability analysis of survey data and since all values are above 0.7 the data is reliable and can be used for further analysis.

\section{Hypothesis Testing}

The researcher used inferential statistics and conducted Multiple Regression Analysis to test the hypotheses and the results are given below in Table 8;

Table 8- Multiple Regression Analysis Results

\begin{tabular}{|l|l|l|l|l|l|l|l|l|}
\hline Variable & $\mathrm{R}$ & $\mathrm{R}^{2}$ & $\begin{array}{l}\text { Adjusted } \\
\mathrm{R}^{2}\end{array}$ & F Value & Sig & $\begin{array}{l}\text { Standardized } \\
\text { Beta }\end{array}$ & $\begin{array}{l}\mathrm{t} \\
\text { value }\end{array}$ & Sig* \\
\hline & 0.456 & 0.208 & 0.189 & 6.732 & 0.072 & & & \\
\hline $\begin{array}{l}\text { Training } \\
\text { and } \\
\text { Developm } \\
\text { ent }\end{array}$ & & & & & & 0.177 & 2.480 & $0.014^{*}$ \\
\hline $\begin{array}{l}\text { Recruitme } \\
\text { nt and } \\
\text { Selection }\end{array}$ & & & & & & 0.138 & 1.957 & $0.052^{*}$ \\
\hline $\begin{array}{l}\text { Compensa } \\
\text { tion and } \\
\text { Rewards }\end{array}$ & & & & & & 0.119 & 1.684 & 0.094 \\
\hline
\end{tabular}

$p^{*} \leqslant 0.05$

The $R^{2}$ value is 0.208 therefore the model is considered as fit to be used for multiple regressions with the data. However, the correlation coefficient $R=0.456$ that reflects there is a positive correlation between Human Resource Management Practices and Perceived Business Performance. The results show that three sub-variables together explained $20.8 \%$ of the variance, where $\left(R^{2}=0.208, F=6.732\right.$, Sig. $=0.072$ ) indicates that the alternative hypothesis rejected and the null hypothesis is accepted. Hence $\mathrm{H}_{1}$ is rejected. This indicates that Human Resource Management Practices (Training and Development, Recruitment and Selection and Compensation and Rewards) do not have a statistically 
INTERNATIONAL JOURNAL OF ACADEMIC RESEARCH IN BUSINESS AND SOCIAL SCIENCES Vol. 10, No. 5, May, 2020, E-ISSN: 2222-6990 @ 2020 HRMARS

significant effect on Perceived Business Performance, at level ( $\alpha \leq 0.05)$. Moreover, this finding is in agreement with Kato and Morishima (2002) which indicated that HRM practices may not have a direct effect to gain better performance but to achieve the expected gains it takes time. Moreover, there is a lack of theory to convince fully that HRM practices connected to firm performance (Singh et al., 2016), and therefore the study finding is further supported.

Table (8) indicates that the training and development sub-variable has the highest contribution to perceived business performance, where (Beta=0.177, sig. $=0.014$ ). Therefore, training and development sub-variable is the most significant, and it positively and directly regresses to perceived business performance. Hence $\mathrm{H} 1 \mathrm{a}$ is supported at level $(\alpha \leq 0.05)$. The finding is in the agreement of Thang et. al (2010) as they indicated training has a positive effect on firm performance. The second highest contributor is the recruitment and selection sub-variable, where (Beta=0.138, sig. $=0.052$ ), and therefore $\mathrm{H} 1 \mathrm{c}$ is also supported at level $(\alpha \leq 0.05)$. This finding is consistent with the previous research finding of Chand and Katou (2007) as they found that recruitment and selection were strongly correlated with profitability. Moreover, the table shows the compensation and rewards, where (Beta=0.119, sig. $=0.094$ ) which means $\mathrm{p}$ is greater than 0.05 , and therefore $\mathrm{H} 1 \mathrm{~b}$ is not supported at level $(\alpha \leq 0.05)$. This result is in agreement with the findings of (Bussin \& Nel, 2015).

Table 9- Hierarchical regression results using firm size as a moderator

\begin{tabular}{|l|l|l|l|}
\hline Variable & $\begin{array}{l}\text { Standardized beta } \\
1\end{array}$ & $\begin{array}{l}\text { Standardized beta } \\
2\end{array}$ & $\begin{array}{l}\text { Standardized beta } \\
2\end{array}$ \\
\hline $\begin{array}{l}\text { Training and } \\
\text { Development }\end{array}$ & 0.204 & 0.194 & 0.155 \\
\hline $\begin{array}{l}\text { Recruitment and } \\
\text { Selection }\end{array}$ & 0.179 & 0.171 & 0.346 \\
\hline $\begin{array}{l}\text { Compensation \& } \\
\text { Rewards }\end{array}$ & 0.171 & 0.164 & 0.086 \\
\hline Firm Age & & 0.092 & 0.170 \\
\hline TD*F & & & 0.083 \\
\hline RS*F & & & -0.387 \\
\hline$C R^{*} F$ & & & 0.199 \\
\hline$R^{2}$ & 0.175 & 0.184 & 0.185 \\
\hline Adj. R2 & 0.163 & 0.168 & 0.157 \\
\hline$R^{2}$ change & 0.175 & 0.008 & 0.001 \\
\hline Sig F Change & 0.000 & 0.155 & 0.957 \\
\hline
\end{tabular}

$*^{* *} p<0.01 \quad \mathrm{p} * 0.05 \quad \mathrm{~N}=210 ;$ Standardized coefficients are presented.

The above table 9 of hierarchical linear regression indicates in Model 1, R Square value of .1757 and when Firm age scores were added as shown in Model 2, the value for R Square increased to .184 $(18.4 \%)$ leading to a difference of 0.009 which means with the addition of Firm Age scores contributes $0.09 \%$ additional variance in perceived business performance. On the same basis when other interaction variables were added in Model 3 the value for $R$ square increased to 0.185 (18.5\%) having an increase of 0.001 giving an additional $0.01 \%$ variance in business performance. Furthermore, in Model 1, then consider the above results only Model 1 is significant as Sig. F Change is less than 0.001 and with the adding of new variable(s) Firm Age (Model2) and after adding interaction variables 
INTERNATIONAL JOURNAL OF ACADEMIC RESEARCH IN BUSINESS AND SOCIAL SCIENCES

Vol. 10, No. 5, May, 2020, E-ISSN: 2222-6990 @ 2020 HRMARS

(Model 3) both models do not produce a statistically increase invariance for the dependent variable of perceived business performance. Therefore, $\mathrm{H} 2$ is not supported. Hence firm age has no moderating effect on the relationship between Human resource management practices and perceived business performance.

\section{Conclusions}

The findings of the research concluded that Human Resource Management Practices per se has no direct significant effect on the perceived business performance of the ISO 9001 quality management system certified manufacturing firms. However, the findings concluded that training and development and recruitment selection have a positive effect on the perceived business performance of firms. This is very important for managers of these firms because training and development as one of the HRM practices played a vital role in enhancing the performance of the ISO 9001 Quality Management System certified firms and accordingly the managers can make the training budget in a more focused manner to develop a talent human capital unique to the organization to gain enhanced performance. Moreover, this finding is equally important for potential manufacturing firms that are intended to adopt and practice the Quality Management System as those firms can also plan out and strengthen the training and development function to enhance the skills of the employees which requires to implement the quality system effectively and efficiently once it is adopted. Moreover, recruitment and selection play another important contribution as the proper human capital is the most important unique asset to any organization. Therefore, selecting the right employees and recruiting them to the organization helps to fill the vacancies appropriately and that helps to strengthen the human capital leading to gain expected contribution to enhancing the firm performance. The findings provide a deeper insight to the managers of these organizations' as even most suitable employees are selected and recruited to the organization the vital fact is to train and retain them using training and development function about the job tasks so that only the employees gain appropriate skills required to perform the tasks effectively and efficiently without making mistakes to achieve the set goals and targets paving the way to bring in enhance positive outcome. The findings also indicate that certain identified practices of Human Resource Management are very much important to strengthen the performance of the organizations as such functions do have contributions for firm performance and therefore managers should provide due attention to those practices of HRM.

Moreover, the findings also proved that the total number of years (Firm Age) that the ISO 9001 Quality Management System (QMS) implemented within the firm does not influence the relationship between Human Resource Management Practices and firm perceived performance. This is an important finding for managers as the years of implementation of QMS have no role in existing HRM practices and firm performance because the managers can plan out the business strategies irrespective of the years that the QMS has been implemented to get the expected gains. This is also important for potential firms as those firms can map out the business strategies like the extent of HRM practices that need to be adjusted in adopting ISO 9001 QMS as firm age is not a barrier when it comes to HRM practices and firm performance.

The hypothesized model used in this study would be a significant theoretical contribution and the findings of this study would also be considerable value to the literature in the context of ISO 9001 certified firms and their journey towards business performance. Furthermore, the present study findings have managerial implications as it gives insightful information to managers about the exact 
variables of Human Resource Management Practices to be considered in implementing the ISO 9001 Quality Management System to achieve enhanced business performance. This is very vital in today's competitive business environment as all certified firms are struggling to get the maximum benefit when achieving ISO 9001 certification. Hence the study findings would support them to have a focused approach to meet that expectation. Furthermore, in the context of ISO 9001 certified firms, the number of years that the quality management system implemented does not affect perceived business performance which is very much important for new manufacturing firms that are intended to enter into ISO 9001 certification to make a considered decision. Not only that the study findings contribute significantly to policymakers, government officials, potential manufacturing firms as it provides insightful information on HRM practices that facilitate the manufacturing firms to gain better performance.

\section{Research Limitation}

The data for the research was collected using a structured questionnaire prepared using the Likert Scale and therefore it may be not possible to go into collect the deeper views of the respondents about the issues. Moreover, the research conducted using ISO 9001 certified manufacturing firms in Sri Lanka and hence there is a limitation to extend the results to non-ISO 9001 certified firms.

\section{Future Research Direction}

For these results, only manufacturing sector firms were considered and therefore it suggested conducting future research using ISO 9001 certified service sector firms as now the service sector is stronger than the manufacturing sector. Furthermore, in future research, appropriate mediating variables with different sub-variables can be considered in designing so that the study so that it adds value to the literature.

\section{References}

Ajila, C., \& Abiola, A. (2004). Influence of rewards on workers' performance in an organization. Journal of Social Sciences, 8(1), 7-12.

Armstrong, M. (2006). A handbook of human resource practice. London and Sterling: Kogan Page Limited.

Armstrong, M. (2009). Armstrong's handbook of performance management: An evidence-based guide to delivering high performance. Kogan Page Publishers.

Barney, J. (1991). Firm resources and sustained competitive advantage. Journal of management, 17(1), 99-120.

Barney, J. B., \& Wright, P. M. (1998). On becoming a strategic partner: The role of human resources in gaining competitive advantage. Human Resource Management: Published in Cooperation with the School of Business Administration, The University of Michigan and in alliance with the Society of Human Resources Management, 37(1), 31-46.

Becker, B., \& Gerhart, B. (1996). The impact of human resource management on organizational performance: Progress and prospects. Academy of management journal, 39(4), 779-801.

Bedi, H. S., \& Vij, S. (2015). How do age, type, size, and nature determine firms' entrepreneurial orientation. International Journal of Applied Business and Economic Research, 13(3), 10151030. 
INTERNATIONAL JOURNAL OF ACADEMIC RESEARCH IN BUSINESS AND SOCIAL SCIENCES

Vol. 10, No. 5, May, 2020, E-ISSN: 2222-6990 @ 2020 HRMARS

Boselie, P., \& Dietz, G. (2003). Commonalities and contradictions in research on human resource management and performance. Paper presented at the Academy of Management Meetings in Seattle, August 2003.

Boxall, P., Ang, S. H., \& Bartram, T. (2011). Analyzing the 'black box of HRM: Uncovering HR goals, mediators, and outcomes in a standardized service environment. Journal of Management Studies, 48(7), 1504-1532.

Brewster, C., Suutari, V., \& Minbaeva, D. B. (2005). HRM practices and MNC knowledge transfer. Personnel review.

Budhwar, P. S., Chand, M., \& Katou, A. A. (2007). The impact of HRM practices on organizational performance in the Indian hotel industry. Employee relations.

Bussin, M., \& Nel, M. (2015). Relationship between CEO remuneration and company financial performance in the South African retail and consumer goods sector. Acta Commercii, 15(1), 1-11.

Crook, T. R., Todd, S. Y., Combs, J. G., Woehr, D. J., \& Ketchen Jr, D. J. (2011). Does human capital matter? A meta-analysis of the relationship between human capital and firm performance. Journal of applied psychology, 96(3), 443.

Dieleman, M., Gerretsen, B., \& van der Wilt, G. J. (2009). Human resource management interventions to improve health workers' performance in low and middle-income countries: a realist review. Health Research Policy and Systems, 7(1), 7.

Djabatey, E. N. (2012). Recruitment and Selection Practices of Organisations: A Case Study of HFC Bank (Gh) Ltd (Doctoral dissertation).

Dyer, L., \& Reeves, T. (1995). Human resource strategies and firm performance: what do we know and where do we need to go?. International Journal of human resource management, 6(3), 656-670.

Elarabi, H. M., \& Johari, F. (2014). The impact of human resources management on healthcare quality. Asian journal of management sciences \& education, 3(1), 13-22.

Fay, C. H., \& Thompson, M. A. (2001). Contextual determinants of reward systems' success: An exploratory study. Human Resource Management: Published in Cooperation with the School of Business Administration, The University of Michigan and in alliance with the Society of Human Resources Management, 40(3), 213-226.

Frye, M. B. (2004). Equity-based compensation for employees: firm performance and determinants. Journal of Financial Research, 27(1), 31-54.

Guthrie, J. P. (2001). High-involvement work practices, turnover, and productivity: Evidence from New Zealand. Academy of management Journal, 44(1), 180-190.

Hassan, A., Hashim, J., \& Ismail, A. Z. H. (2006). Human resource development practices as a determinant of HRD climate and quality orientation. Journal of European Industrial Training.

Hair, J. F., Black, W. C., Babin, B. J., Anderson, R. E., \& Tatham, R. L. (1998). Multivariate data analysis (Vol. 5, No. 3, pp. 207-219).

Holzer, H. J., Block, R. N., Cheatham, M., \& Knott, J. H. (1993). Are training subsidies for firms effective? The Michigan experience. ILR Review, 46(4), 625-636.

Huselid, M. A. (1995). The impact of human resource management practices on turnover, productivity, and corporate financial performance. Academy of management journal, 38(3), 635-672. 
INTERNATIONAL JOURNAL OF ACADEMIC RESEARCH IN BUSINESS AND SOCIAL SCIENCES

Vol. 10, No. 5, May, 2020, E-ISSN: 2222-6990 @ 2020 HRMARS

Hutchinson, S., Kinnie, N., \& Purcell, J. (2002). Bringing Policies to Life: discretionary behaviour and the impact on business performance. Management, 10, 11.

Jiang, K., Lepak, D. P., Hu, J., \& Baer, J. C. (2012). How does human resource management influence organizational outcomes? A meta-analytic investigation of mediating mechanisms. Academy of management Journal, 55(6), 1264-1294.

Kato, T., \& Morishima, M. (2002). The productivity effects of participatory employment practices: Evidence from new Japanese panel data. Industrial Relations: A Journal of Economy and Society, 41(4), 487-520.

Lai, Y. (2013). The moderating effect of organizational structure in knowledge management for international ports in Taiwan. International journal of computer and information technology, 2(2), 240-246.

Lee, C. H., \& Bruvold, N. T. (2003). Creating value for employees: investment in employee development. The International Journal of Human Resource Management, 14(6), 981-1000.

Lee, F. H., \& Lee, F. Z. (2007, November). The relationships between HRM practices, Leadership style, competitive strategy, and business performance in the Taiwanese steel industry. In Proceedings of the 13th Asia Pacific Management Conference, Melbourne, Australia (Vol. 2007, pp. 953-971).

Lepak, D. P., Liao, H., Chung, Y., \& Harden, E. E. (2006). A conceptual review of human resource management systems in strategic human resource management research. Research in personnel and human resources management, 25(1), 217-271.

MacDuffie, J. P. (1995). Human resource bundles and manufacturing performance: Organizational logic and flexible production systems in the world auto industry. ilr Review, 48(2), 197-221.

Mansour, M. (2010). Human Resource Practices Impact on Firm Performance: An Empirical Study. King Fahd University of Petroleum and Minerals, 1(3), 6-34.

Noe, R., Hollenbeck, J., Gerhart, B., and Wright, P. (2010). Human Resource Management: Gaining a Competitive Advantage. McGraw Hill, New York.

Ntiamoah, E. B., Abrokwah, E., Agyei-Sakyi, M., Opoku, B., \& Siaw, A. (2014). An investigation into recruitment and selection practices and organizational performance. International Journal of Economics, Commerce and Management, 2(11), 1-11.

Obasan, K. A. (2012). Effect of compensation strategy on corporate performance: Evidence from Nigerian firms. Research Journal of Finance and Accounting, 3(7), 37-44.

Pao-Long, C., \& Wei-Ling, C. (2002). The effect of human resource management practices on firm performance: Empirical evidence from high-tech firms in Taiwan. International Journal of Management, 19(4), 622.

Rafiq, S., Salim, R., \& Smyth, R. (2016). The moderating role of firm age in the relationship between $R \& D$ expenditure and financial performance: Evidence from Chinese and US mining firms. Economic Modelling, 56, 122-132.

Rauf, M. A. (2007). HRM sophistication and SME performance: a case of readymade garment manufacturers and exporters in Lahore, Pakistan (Master's thesis, University of Twente).

Sarkar, A., \& Kumar, S. (2007). Effective recruitment and selection: An approach towards a model building. HRM Review, 7(7), 15-22.

Shaw, J. D., Gupta, N., \& Delery, J. E. (2005). Alternative conceptualizations of the relationship between voluntary turnover and organizational performance. Academy of management journal, 48(1), 50-68. 
INTERNATIONAL JOURNAL OF ACADEMIC RESEARCH IN BUSINESS AND SOCIAL SCIENCES

Vol. 10, No. 5, May, 2020, E-ISSN: 2222-6990 @ 2020 HRMARS

Shaw, J. D., Park, T. Y., \& Kim, E. (2013). A resource-based perspective on human capital losses, HRM investments, and organizational performance. Strategic management journal, 34(5), 572589.

Singh, S., Darwish, T. K., \& Potočnik, K. (2016). Measuring organizational performance: A case for subjective measures. British Journal of Management, 27(1), 214-224.

Soliman, F., \& Spooner, K. (2000). Strategies for implementing knowledge management: the role of human resources management. Journal of knowledge management.

Swanson, R. A. (1995). Human resource development: Performance is key. Human resource development quarterly, 6(2), 207-213.

Thang, N. N., Truong, Q., \& Buyens, D. (2010). The relationship between training and firm performance-A literature review.

Vance, R. J. (2012). Employee Engagement and Commitment, A Guide to Understanding, Measuring, and Increasing Engagement in your Organization. SHRM Foundation's Practice Guidelines, Alexandria, VA, 22314.

Youndt, M. A., Snell, S. A., Dean Jr, J. W., \& Lepak, D. P. (1996). Human resource management, manufacturing strategy, and firm performance. Academy of management Journal, 39(4), 836866. 